\title{
PENGARUH PENDEKATAN OPEN ENDED PROBLEM TERHADAP HASIL BELAJAR MATEMATIKA SISWA KELAS VII
}

\author{
Sirwanti ${ }^{1}$, Riska $^{2}$ \\ sirwanti89@gmail.com ${ }^{1}$ \\ Program Studi Pendidikan Matematika, STKIP Muhammadiyah Bone $e^{1,2}$
}

\begin{abstract}
This study aims to determine how the influence of the open-ended problem approach to the students' mathematics learning outcomes at grade VII SMP Muhammadiyah Walattasi, Soppeng Regency. The researcher used 2 classes; experimental and control class. This study used a Nonequivalent Control Group Design with quasi-experimental type. The research population is students of grade VII SMP Muhammadiyah Walattasi, Soppeng Regency. Learning outcome data is processed using independent T-test samples through normality prerequisite tests (Kolmogorof Smirnov) and homogeneity tests for variance in statistical tests with significance level $(\alpha=0$.05). Data were processed by utilizing SPSS version 23 software. The results of hypothesis testing indicated that Tcount> Ttable or 4,561> 2,011, like to see sig data. ( 2 tailed) the experimental class and the control class $0,000<0.05$, Based on these results, it could be conclude that there is an influence of the open-ended problem approach to the students' mathematics learning outcomes at grade VII SMP Muhammadiyah Walattasi, Soppeng Regency.
\end{abstract}

Kata Kunci: open-ended problem; Students' Mathematics learning outcome

\section{PENDAHULUAN}

Pendidikan merupakan suatu kebutuhan yang harus dipenuhi dalam kehidupan bermasyarakat, berbangsa dan bertanah air. Maju mundurnya suatu bangsa ditentukan oleh kreativitas pendidikan bangsa itu sendiri dan kompleknya masalah kehidupan menuntut sumber daya manusia yang handal dan mampu berkompetensi. Selain itu, pendidikan merupakan wadah kegiatan yang dapat dipandang sebagai pencetak sumber daya manusia 
yang bermutu tinggi. Pendidikan bukanlah suatu hal yang statis atau tetap, melainkan suatu hal yang dinamis sehingga menuntut adanya suatu perubahan atau perbaikan secara terus menerus. Perubahan dapat dilakukan dalam hal metode mengajar, buku-buku, alat-alat laboratorium, maupun materi-materi pelajaran.

Matematika merupakan salah satu mata pelajaran yang menduduki peranan penting dalam pendidikan. Hal ini dapat dilihat dari waktu jam pelajaran sekolah lebih banyak dibanding pelajaran lain. Pelajaran matematika dalam pelaksanaan pendidikan diberikan kepada semua jenjang pendidikan mulai dari taman kanak-kanak sampai sekolah menengah atas. Pembelajaran di SMP adalah upaya untuk mengembangkan potensi, kecakapan dan kepribadian siswa. Perkembangan aspek-aspek pada siswa tersebut tidak diberikan oleh guru, tetapi siswa sendiri yang berusaha mengembangkan dirinya. Fungsi guru hanyalah menciptakaan situasi, memberikan dorongan, arahan, bimbingan dan kemudahan agar siswa dapat belajar dan mengembangkan dirinya. Menurut Annurrahman (2012) bahwa dalam proses pembelajaran, interaksi siswa dipengaruhi berbagai faktor, antara lain: Karakteristik dan perkembangan siswa, Intelektual dalam belajar, Transfer dalam belajar dan Penyesuaian pembelajaran dengan perbedaan intelektual. Salah satu hambatan dalam pelajaran matematika adalah bahwa siswa kurang tertarik pada matematika.

Berdasarkan observasi awal yang dilakukan doleh peneliti di lokasi penelitian ditemukan bahwa masih banyak siswa yang mengalami kesulitan bila menghadapi soal soal matematika dan mengakibatkan hasil belajar matematika yang rendah. Suatu kesalahan yang sering terjadi adalah guru kurang memperhatikan tingkat pemahaman siswa dalam mengikuti perubahan, langkah, tahap demi tahap dalam penyampaian materi pelajaran. Dengan kata lain, siswa hanya dibuat tercengang oleh guru dalam mempermainkan rumus yang begitu runtun dalam sebuah rangkaian indikator ketercapaian.

Kondisi ini mungkin bagi guru suatu pekerjaan yang remeh jika sekedar menulis rumus yang sebenarnya dapat dijadikan sebagai penuntun siswa dalam memahami materi dan menyelesaikan soal-soal. Hasil pembelajaran yang telah dilaksanakan seorang guru terkadang tidak sesuai dengan harapan. Untuk melihat hasil pembelajaran yang telah dilaksanakan salah satunya dengan melihat nilai dan keterampilan siswa dalam pembelajaran itu. Apabila nilai perolehan siswa jauh dari harapan, maka seorang guru harus memperbaiki pembelajaran agar kompetensi yang telah ditetapkan kurikulum dapat tercapai sesuai dengan harapan. 
Berdasarkan kualitas proses siswa masih cenderung pasif dalam proses belajar mengajar, sementara diharapkan siswa dapat secara aktif terlibat dalam proses belajar mengajar yang dilaksanakan. Sebagai tenaga pengajar/pendidik yang secara langsung terlibat dalam proses belajar mengajar, maka guru memegang peranan penting dalam menentukan peningkatan kualitas pembelajaran dan hasil belajar yang akan dicapai siswanya. Salah satu kemampuan yang diharapkan dikuasai oleh pendidik dalam hal ini adalah bagaimana mengajarkan matematika dengan baik agar tujuan pengajaran dapat dicapai semaksimal mungkin (Djamarah, 2010). Penguasaan materi dan cara pemilihan pendekatan atau teknik pembelajaran yang sesuai dengan menentukan tercapainya tujuan pengajaran. Demikian juga halnya dengan proses pembelajaran. Untuk mencapai tujuan pembelajaran, perlu disusun suatu strategi agar tujuan itu tercapai dengan optimal. Tanpa suatu strategi yang cocok, tepat dan jitu, tidak mungkin tujuan dapat tercapai.

Pembelajaran yang selama ini dikenal adalah pembelajaran yang berbasis konvensional, maksudnya adalah pembelajaran yang masih berpusat pada guru (Teacher Center). Pembelajaran konvensional menjadikan guru adalah satu-satunya sumber informasi bagi siswa. Posisi siswa adalah pendengar dan hanya terkesan menjadi penerima tanpa harus bertanya tentang proses tersebut. Gaya mengajar seperti ini membuat kreativitas siswa menjadi terhambat dan kebanyakan siswa mengalami kesulitan dalam matematika disituasi kehidupan real (Abdurrahman, 2003).

Berdasarkan hasil observasi pada SMP Muhammadiyah Walattasi Kab. Soppeng, sulitnya menumbuhkan minat atau ketertarikan belajar siswa juga dialami oleh peneliti yang berpengaruh pada rendahnya hasil belajar matematika siswa. Rendahnya minat serta hasil belajar matematika siswa di kelas di duga karena guru secara aktif menjelaskan materi, member contoh, dan latihan, sedangkan siswa hanya mendengar, mencatat dan mengerjakan. Akibatnya siswa cenderung pasif dan hanya menerima informasi dari guru saja, sehingga siswa tidak mampu mengembangkan kreatifitasnya sendiri karena merasa takut salah untuk menggunakan cara yang berbeda dalam penyelesaian soal matematika.

Pembelajaran konvensional yang seperti ini kurang memberikan kesempatan pada siswa untuk menentukan, membentuk dan mengembangkan pengetahuannya sendiri. Oleh sebab itu pembelajaran tersebut kurang mampu menumbuhkan ninat belajar dalam diri sendiri, serta sangat kecil peluang terjadinya proses sosial antar siswa yaitu hubungan siswa satu dengan siswa lainnya dalam rangka membangun pengetahuan bersama. 
Berdasarkan penerapannya masih banyak guru yang mengabaikan kemampuan siswa. Khususnya guru mata pelajaran Matematika yang masih menggunakan konsep pembelajaran yang berpusat pada guru atau masih menggunakan metode ceramah (teacher centered), sehingga siswa-siswa terbiasa mengandalkan contoh penyelesaian soal dari guru dan buku pegangan matematika (closed ended). Hal seperti ini dapat menjadikan siswa selalu merasa takut salah untuk menggunakan cara yang berbeda dalam penyelesaian soalsoal matematika.

Cara mengatasi hal tersebut diperlukan bimbingan dan kepercayaan penuh dari guru sebagai motivasi terhadap siswa dalam mengeksplorasi pengetahuannya untuk memecahkan masalah dalam pembelajaran matematika (student centered). Selain itu, seorang guru juga membutuhkan suatu model pembelajaran aktif yang berbasis masalah sebagai acuan dalam proses pembelajaran matematika. Dengan memiliki acuan sebuah model atau pendekatan pembelajaran seorang guru akan mampu menerapkan teknik dan strategi atau pendekatan pembelajaran sesuai tujuan pada model pembelajaran yang digunakan juga tujuan yang ingin dicapai dalam indikator-indikator materi pembelajaran yang disampaikan (Hamalik, 2004)

Salah satu upaya yang dapat dilakukan oleh pendidik adalah melakukan inovasi dalam pembelajaran dalam rangka mengoptimalkan hasil akademik/hasil belajar maka dikembangkanlah pendekatan-pendekatan pembelajaran yang menekankan pada pentingnya penyesuaian belajar siswa, sehingga siswa tidak mudah lupa dengan pelajaran yang baru saja diterima dan siswa bisa berpartisipasi aktif dan mengekspresikan idenya.Salah satu dari model-model atau pendekatan pembelajaran yang baik untuk di pertimbangkan oleh seorang pendidik tersebut adalah Open EndedProblem. Menurut Heddeas dan Speer (khaeriyyah, 2009 : 16) Open Ended Problem yaitu suatu pendekatan pembelajaran yang memberi keleluasaan berfikir siswa secara aktif dan kreatif dalam menyelesaikan suatu permasalahan.

Pembelajaran Open Ended Problem mengarahkan peserta didik menyelesaikan masalah dengan cara atau bisa saja dengan jawaban yang berbeda, sehingga dapat menumbuhkan minat belajar siswa. Menurut Hidayat (2018) Open Ended Problem salah satu pendekatan pembelajaran yang ada didalam pembelajaran aktif dan memiliki unsurunsur pembelajaran inovatif yang berbasis masalah, sehingga diharapkan dapat membantu guru untuk meningkatkan kemampuan siswa dalam pemecahan masalah matematika.Berdasarkan uraian di atas, penulis tertarik untuk mengadakan penelitian 
tentang "Pengaruh Pendekatan Open Ended Problem Terhadap Hasil Belajar Matematika Siswa Kelas VII SMP Muhammadiyah Walattasi”.

\section{METODE PENELITIAN}

\section{Jenis Penelitian dan Sampel}

Pada penelitian ini penulis menggunakan metode penelitian eksperimen semu (Quasi Experiment). Desain ini memiliki kelompok kontrol, tetapi tidak dapat berfungsi sepenuhnya untuk mengontrol variabel-variabel luar yang mempengaruhi pelaksanaan eksperimen Jenis penelitian ini menggunakan dua kelas yaitu kelas kontrol dan kelas eksperimen. Model pembelajaran kelas kontrol adalah modelpembelajaran langsung, sedangkan pada kelas eksperimen dilakukan dengan menerapkan pendekatan pembelajaran terbuka (Open Ended Problem).

\section{Lokasi Dan Waktu Penelitian}

Penelitian ini dilaksanakan di SMP Muhammadiyah Walattasi Kab. Soppeng, dengan subjek penelitian siswa kelas VII. Penelitian ini dilaksanakan pada semester genap tahun ajaran 2017/2018.

\section{Populasi dan Sampel}

\section{Populasi}

Populasidalam penelitian ini adalah seluruh kelas VII SMP Muhammadiyah Walattasi kab. Soppeng. Keadaan populasi dapat dilihat pada tabel 1 berikut

Tabel 1. Populasi Penelitian

\begin{tabular}{ccccc}
\hline \multirow{2}{*}{ No. } & \multirow{2}{*}{ Kelas } & \multicolumn{2}{c}{ Siswa } & \multirow{2}{*}{ Jumlah } \\
\cline { 3 - 4 } & VII A & Laki-laki & Perempuan & \\
\hline 1 & VII B & 12 & 13 & 25 \\
2 & Jumlah siswa & 25 & 12 & 25 \\
\hline \multicolumn{4}{r}{} & \multicolumn{3}{c}{ (Sumber : SMP Muhammadiyah Walattasi) }
\end{tabular}

\section{Sampel}

Sampel dalam penelitian ini terdiri dari dua kelas yaitu kelas eksperimen dan kelas kontrol. Dimana kelas VII A sebagai kelas eksperimen, dan kelas VII B sebagai kelas kontrol. Karena semua populasi adalah sampel, maka sampel dalam penelitian ini adalah 
sampel jenuh (Sugiyono, 2016). Adapun yang menjadi sampel dalam penelitian ini, dapat dilihat pada tabel 2.

Tabel 2.Sampel penelitian

\begin{tabular}{lrccc}
\hline \multirow{2}{*}{ No. } & \multirow{2}{*}{ Kelas } & \multicolumn{2}{c}{ Siswa } & \multirow{2}{*}{ Jumlah } \\
\cline { 3 - 4 } & & Laki-laki & Perempuan & \\
\hline 1 & VII A & 12 & 13 & 25 \\
2 & VII B & 13 & 12 & 25 \\
\cline { 3 - 5 } & Jumlah siswa & 25 & 25 & 50 \\
\hline
\end{tabular}

(Sumber : SMP Muhammadiyah Walattasi)

\section{Desain Penelitian}

Desain penelitian yang digunakan adalah Nonequivalent Control Group Design. Design ini hampir sama dengan Pretest-Posttest Control Group Design, tetapi desain ini kelas kontrol dan kelas eksperimen tidak dipilih secara acak. Kelas eksperimen diberi pelajaran dengan menggunakan pendekatan Open Ended Problem dan kelas kontrol diberi pelajaran dengan menggunakan model pembelajaran langsung. Sebelum perlakuan diberi Pre-test untuk mengukur keadaan awal kedua kelas. Setelah perlakuan, kedua kelas diberikan Post-test untuk mengukur hasil belajar siswa. Design penelitian ini dapat digambarkan sebagai berikut:

Gambar1. Nonequivalent Control Group Design

\begin{tabular}{|lll|}
\hline $\mathrm{O}_{1}$ & $\mathrm{~T}_{1}$ & $\mathrm{O}_{2}$ \\
\hline $\mathrm{O}_{3}$ & $\mathrm{~T}_{2}$ & $\mathrm{O}_{4}$ \\
\hline
\end{tabular}

Keterangan:

$\mathrm{O}_{1}$ : Pre-testpadakelas eksperimen

$\mathrm{O}_{2}:$ Post-testpada kelaseksperimen

$\mathrm{O}_{3}$ : Pre-test pada kelas kontrol

$\mathrm{O}_{4}$ : Post-test pada kelas kontrol

$\mathrm{T}_{1}$ : Perlakuan/ pengajaran dengan menggunakan pendekatan Open Ended Problem

$\mathrm{T}_{2}$ : Tanpa ada perlakuan pendekatan Open Ended Problem

\section{Instrumen Penelitian}

Instrumen yang digunakan dalam penelitian ini adalah tes hasil belajar. Tes hasil belajar adalah cara penilaian yang dirancang dan dilaksanakan kepada peserta didik pada 
waktu dan tempat tertentu serta dalam kondisi yang memenuhi syarat-syarat tertentu yang telah dijelaskan. Tes hasil belajar yang akan digunakan berupa tes essai (essay test) yang sesuai dengan materi yang diajarkan baik pada kelas eksperimen maupun kelas kontrol.

\section{Teknik Pengumpulan Data}

Teknik pengumpulan data yang dilakukan dalam penelitian ini adalah melalui pemberian tes hasil belajar. Tes hasil belajar dalam penelitian ini berupa Pre-test yang diberikan sebelum perlakuandan Post-test yang diberikan setelah pemberian perlakuan terhadap pendekatan pembelajaran Open Ended Problem.

Pemberianskordilakukanberdasarkanpedoman penskoran yang disusunberdasarkan indikator hasil belajar.

\section{Teknik Analisis Data}

\section{Hasil belajar}

1. Analisis statistik deskriptif

Data hasil belajar yang terkumpul pada penelitian ini dianalisis dengan menggunakan analisis statistik deskriptif meliputi penyajian data melalui tabel, perhitungan mean, modus, median dan standar deviasi. Selanjutnya, nilai yang diperoleh dikelompokkan berdasarkan kriteria nilai ketuntasan belajar siswa yang ditetapkan oleh pihak SMP Muhammadiyah Walattasi Kab. Soppeng seperti pada tabel 3

Tabel 3. Kriteria Nilai Ketuntasan Belajar Siswa

\begin{tabular}{cc}
\hline Tingkat Ketuntasan & Kategori \\
\hline$\geq 75$ & Tuntas \\
$<75$ & Tidak Tuntas \\
\hline
\end{tabular}

(Sumber : SMP Muhammadiyah Walattasi)

2. Analisis statistik inferensial

Analisis statistik inferensial melalui analisis perbandingan antara kelas eksperimen dan kelas kontrol untuk mengetahui pengaruh pendekatan Open Ended Problem terhadap hasil belajar siswa. Hipotesis dalam penelitian ini diuji melalui statistik inferensial dengan menggunakan uji t. Sebelum dilakukan uji hipotesis terlebih dahulu dilakukan uji prasyarat kesamaan. Data penelitian ini dianalisis dengan menggunakan software windows SPSS (Statistical Packaged for Social Science) versi 23. 


\section{a. Uji Prasyarat}

Syarat yang harus dipenuhi sebelum melakukan pengujian terhadap hipotesis adalah melakukan pengujian normalitas dan homogenitas.

1) Uji Normalitas

Uji normalitas diperlukan untuk menguji apakah sampel data berdistribusi normal atau tidak. Uji normalitas disini menggunakan uji Kolmogorov-Smirnov. Pengujian hipotesis yang akan diuji adalah sebagai berikut:

$\mathrm{H}_{0}$ : Populasi tidak berdistribusi normal

$\mathrm{H}_{1}$ : Populasi berdistribusi normal

Kriteria pengujian apabila nilai probabilitas lebih besar dari taraf signifikansi lebih besar dari 5\% atau 0,05 $\left(\mathrm{P}_{\text {value }}>0,05\right)$ maka $\mathrm{H}_{1}$ diterima dan $\mathrm{H}_{0}$ di tolak.

\section{2) Uji Homogenitas}

Uji homogenitas digunakan untuk mengetahui apakah kedua kelompok data yang diteliti berasal dari populasi yang homogen atau tidak. Uji homogenitas dilakukan dengan menggunakan uji Levene Statistic. Pengujian hipotesis yang akan diuji adalah sebagai berikut:

$\mathrm{H}_{0}$ : Populasi variansi tidak homogen

$\mathrm{H}_{1}$ : Populasi variansi homogen

Kriteria pengujian apabila nilai probabilitas lebih besar dari taraf signifikansi lebih besar dari 5\% atau 0,05 ( $\left.\mathrm{P}_{\text {value }}>0,05\right)$ maka $\mathrm{H}_{1}$ diterima dan $\mathrm{H}_{0}$ di tolak.

b. Pengujian Hipotesis

Uji t digunakan untuk mengetahui hipotesis dalam penelitian ini. Pengujian hipotesis dilakukan dengan bantuan program SPSS dengan uji independent sample T-test, atau dengan rumus

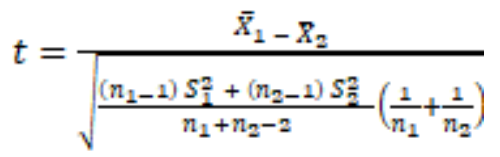

Pengujian hipotesis yang akan diuji adalah sebagai berikut:

Ho : Tidak ada pengaruh pendekatan Open Ended Problem terhadap hasil belajar matematika siswa kelas VII SMP Muhammadiyah Walattasi Kab. Soppeng.

$H_{1} \quad$ : Ada pengaruh pendekatan Open Ended Problem terhadap hasil belajar matematika siswa kelas VII SMP Muhammadiyah Walattasi Kab. Soppeng.

Kriteria pengujian apabila nilai probabilitas lebih kecil dari taraf signifikansi lebih kecil dari $5 \%$ atau 0,05 adalah jika $t_{\text {hitung }}>\mathrm{t}_{\text {tabel }}$ maka Ho ditolak, akan tetapi jika $\mathrm{t}_{\text {hitung }}<\mathrm{t}_{\text {tabel }}$ maka Ho diterima. 


\section{HASIL DAN PEMBAHASAN}

Penelitian ini bertujuan untuk mengetahui pengaruh pendekatan Open Ended Problem terhadap hasil belajar matematika siswa. Peneliti membandingkan hasil belajar siswa pada kelas VII A (kelas eksperimen) yang diberi pendekatan Open Ended Problemdengan hasil belajar siswa yang tidak diberi pendekatan Open Ended Problem pada kelas kontrol yaitu kelas VII B. Kedua kelas sebelumnya diberi tes sebelum proses pembelajaran (Pre-tes) yang terdiri dari 7 butir soal essay yang berkaitan dengan mata pelajaran segiempat dan segitiga, kemudian kedua kelas tersebut masing-masing dibelajarkan dengan model / pendekatan yang berbeda.

Pemberian pendekatan Open Ended Problemterhadap hasil belajar siswa lebih baik dibandingkan dengan tidak menggunakan pendekatan Open Ended Problem. Nilai mean, median, modus kelas eksperimen yang lebih tinggi dibanding dengan kelas kontrol. Selain itu, pemberian pendekatan Open Ended Problemjuga memberikanpengaruh positif terhadap hasil belajar siswa kelas VII SMP Muhammadiyah Walattasi untuk materi pokok segitiga dan segiempat. Hasil perhitungan pengujian hipotesis menggunakan uji-t menunjukkan bahwa nilai thitung $>t_{\text {tabel, }}$ sehingga $\mathrm{H}_{1}$ diterima dan $\mathrm{H}_{0}$ ditolak, yang berarti bahwa pendekatan Open Ended Problem berpengaruh positif terhadap hasil belajar siswa untuk materi pokok segitiga dan segiempat.

Berdasarkan beberapa tabel diatas dapat diketahui bahwa nilai rata-rata Pre-Test pada kelas kontrol diperoleh nilai sebesar $(48,24)$ dan persentase siswa yang tidak tuntas mencapai (92\%) yaitu terdapat 23 siswa, serta hanya terdapat $2(8 \%)$ siswa yang dinyatakan tuntas. Sedangkan nilai rata-rata pada kelas eksperimen sebesar $(61,56)$, dengan persentase siswa yang dinyatakan tidak tuntas yaitu mencapai (80\%) atau 20 siswa, dan hanya terdapat 5 atau $(20 \%)$ orang siswa yang dinyatakan tuntas.

Setelah dilakukan perlakuan dengan menerapkan pendekatan Open Ended Problem pada kelas eksperimen dan menerapkan model pembelajaran langsung pada kelas kontrol., selanjutnya dilakukan pengumpulan data Post-test. Data Post-test yang diperoleh dari hasil belajar kelas eksperimen dengan nilai rata-rata sebesar $(84,56)$ dengan persentase siswa yang dinyatakan tuntas meningkat menjadi (80\%) atau telah mencapai 20 siswa dan hanya (20\%) atau 5 orang siswa yang dinyatakan tidak tuntas. Yang dinyatakan lebih tinggi dari nilai ratarata kelas kontrol yang hanya sebesar $(70,16)$ atau hanya mencapai $(44 \%)$ siswa yang dinyatakan tuntas atau hanya 11 orang siswa, dan selebihnya (56\%) atau 14 siswa yang 
dinyatakan masih tidak tuntas. Hal ini membuktikan bahwa penerapan pendekatan Open Ended Problem lebih baik dibandingkan dengan model pembelajaran langsung.

Hasil perhitungan analisis statistik nilai rata-rata pada data Pre-test yang telah dilakukan pada siswa kelas eksperimen memang lebih tinggi dibanding dengan kelas kontrol. Akan tetapi, setelah kedua kelas diberi perlakuan dengan model / pendekatan pembelajaran yang berbeda menunjukkan kenaikan signifikan nilai rata-rata kelas eksperimen dibandingkan kelas kontrol. Hal ini membuktikan bahwa dengan pendekatan Open Ended Problem yang diterapkan pada kelas eksperimen berhasil meningkatkan hasil belajar siswa.

Pendekatan Open Ended Problemyaitu pendekatan pembelajaran yang dirancang dan dikembangkan untuk mengembangkan kemampuan kreativitas siswa dalam menuangkan ide-idenya dalam menyelesaikan soal / masalah, dengan demikian siswa dapat aktif dalam berfikir saat proses pembelajaran berlangsung. Hal ini sejalan dengan pendapatHeddeas dan Speer (Khaeriyyah, 2009 : 16) mengemukakan bahwa Open Ended Problem, yaitu: "Suatu pendekatan pembelajaran yang memberi keleluasaan berpikir siswa secara aktif dan kreatif dalam menyelesaikan suatu permasalahan", dan sejalan pula dengan pendapat Ujang Wihatma (Khaeriyyah, 2009 : 16) bahwa pendekatan Open Ended Problem, yaitu:Suatu metode untuk mengungkap kemampuan komunikasi matematika siswa yang meliputi tiga aspek yaitu kemampuan memberikan alasan rasional terhadap pernyataan yang disediakan, kemampuan mengubah bentuk uraian ke dalam model matematika dan kemampuan mengilustrasikan ide-ide matematika ke dalam bentuk uraian yang relevan.Hasil penelitian ini menguatkan penelitian terdahulu tentang pembelajaran menggunakan pendekatan Open Ended Problem yang dilakukan oleh Lely Lailatus Syarifah (2017) “ Pengaruh pendekatan Open Ended Terhadap Kemampuan Berfikir Matematika Siswa".Hasil penelitian ini juga menguatkan penelitian terdahulu tentang peggunaan pendekatan Open Ended Problem yang dilakukan oleh Andi Widyawarsi (2013) “Meningkatkan Kreativitas Belajar Matematika Melalui Pendekatan OpenEnded Problem Pada Siswa Kelas VII B Mts. Muallimin Muhammadiyah Makassar.

Data hasil analisis statistik deskriptif yang diperoleh selanjutnya diolah untuk keperluan analisis data inferensial yang bertujuan untuk pengujian hipotesis, hasil analisis inferensial dan hasil uji hipotesis dengan menggunakan uji independent sample T-test. Berdasarkan analisis Independent sample T-test melalui statistical Packaging For the Social Science (SPSS) for windows versi 23 data Pre-tes, diperoleh nilai untuk $t_{\text {hitung }}$ sebesar 3,071 
dan didapatkan nilai $\mathrm{t}_{\text {tabel }}$ dengan taraf signifikan $\alpha=0,05, \mathrm{db}=\mathrm{n}_{1}+\mathrm{n}_{2}-2=25+25-2=48$ yaitu 2,011, maka nilai $t_{\text {hitung }}>\mathrm{t}_{\text {tabel }}$ atau 3,071 > 2,011, adapun jika melihat dari data sig.(2 tailed) kelas eksperimen dan kelas kontrol sebesar 0,004 $<0,05$. Hal ini berarti $\mathrm{H}_{1}$ diterima dan $\mathrm{H}_{0}$ ditolak. Untuk data Post-test, diperoleh nilai untuk thitung sebesar 4,561 dan didapatkan nilai tabel dengan taraf signifikan $\alpha=0,05, \mathrm{db}=\mathrm{n}_{1}+\mathrm{n}_{2}-2=25+25-2=48$ yaitu 2,011, maka nilai $t_{\text {hitung }}>\mathrm{t}_{\text {tabel }}$ atau 4,561 $>2,011$, adapun jika melihat dari data sig. (2 tailed) kelas eksperimen dan kelas kontrol sebesar 0,000 $<0,05$. Hal ini berarti $\mathrm{H}_{1}$ diterima dan $\mathrm{H}_{0}$ ditolak.

Berdasarkan pembahasan diatas, dapat dikatakan bahwa ada pengaruh positif pendekatan Open Ended Problem terhadap hasil belajar matematika siswa kelas VII SMP Muhammadiyah Walattasi Kabupaten Soppeng.

\section{KESIMPULAN DAN SARAN}

Berdasarkan penelitian yang telah dilaksanakan disertai dengan analisis statistik menunjukkan bahwa nilai rata-rata Post-test kelas eksperimen sebesar $(84,56)$ dan nilai ratarata Post-test kelas kontrol sebesar $(70,16)$ dengan derajat kebebasan $(\mathrm{dk})=\mathrm{n}_{1}+\mathrm{n}_{2}-2=25+$ $25-2=48$. Taraf signifikan $\alpha=0,05$ dengan jumlah sampel $(\mathrm{n})=25$. Berdasarkan perhitungan uji hipotesis yang telah dilaksanakan diperoleh nilai $t_{\text {hitung }}>t_{\text {tabel }}$ atau 4,561 $>$ 2,011, adapun jika melihat dari data sig.(2 tailed) kelas eksperimen dan kelas kontrol sebesar $0,000<0,05$ maka $\mathrm{H}_{1}$ diterima dan $\mathrm{H}_{0}$ ditolak sehingga dapat disimpulkan bahwa terdapat perbedaan hasil Post-test antara siswa kelas eksperimen dan kelas kontrol. Hasil perhitungan pengujian hipotesis menggunakan uji-t menunjukkan bahwa nilai $t_{\text {hitung }}>t_{\text {tabel, }}$, sehingga $H_{1}$ diterima dan $\mathrm{H}_{0}$ ditolak, yang berarti bahwa pendekatan Open Ended Problem berpengaruh positif terhadap hasil belajar siswa untuk materi pokok segitiga dan segiempat. Hal ini berarti ada pengaruh penerapan pendekatan Open Ended Problem terhadap hasil belajar siswa kelas VII SMP Muhammadiyah Walattasi Kab. Soppeng.

Berdasarkan kesimpulan diatas, maka peneliti mengemukakan beberapa saran, yaitu sebagai berikut:

1. Kepada guru bidang studi mata pelajaran matematika, hendaknya memperhatikan situasi dan gejala yang menyebabkan hasil belajar siswa rendah dan berusaha menemukan alternatif pemecahannya 
2. Sebelum proses pembelajaran berlangsung hendaknya guru mempersiapkan model pembelajaran yang tepat guna memperlancar proses pembelajaran sehingga hasil belajar dapat meningkat

3. Dalam memilih model pembelajaran sebaiknya lebih berpusat kepada siswa sehuingga siswa tidak cenderung pasif dan dapat lebih memotivasi siswa dalam belajar yang pada akhirnya dapat meningkatkan hasil belajar siswa.

4. Bagi peneliti lain yang ingin menerapkan bentuk pembelajaran ini, dapat melakukan penelitian yang sama dengan materi yang berbeda.

\section{DAFTAR PUSTAKA}

Abdurrahman, M. (2003). Pendidikan bagi anak berkesulitan belajar. Jakarta: Rineka Cipta. Aunurrahman. (2012). Belajar dan Pembelajaran. Bandung: Alfabeta.

Djamarah, S. B., \& Zain, A. (2010). Strategi belajar mengajar, Jakarta: PT. Rineka Cipta.

Fitri, R. (2014). Penerapan strategi the firing line pada pembelajaran matematika siswa kelas XIIPSSMANegeri 1 Batipuh. Jurnal Pendidikan Matematika, 3(1).

Hamalik, O. (2004). Proses belajar mengajar. Jakarta: Bumi Aksara.

Hidayat, W., \& Sariningsih, R. (2018). Kemampuan pemecahan masalah matematis dan adversity quotient siswa SMP melalui pembelajaran open ended. JNPM (Jurnal Nasional Pendidikan Matematika), 2(1), 109-118.

Sugiyono. (201). Penelitian Kuanttatif, Penelitian Kualitatif dan $R \& D$. Bandung: Remaja Rosdakarya.

Syarifah, L. L. (2019). Pengaruh pendekatan open ended terhadap kemampuan berpikir kritis matematik siswa. Prima: Jurnal Pendidikan Matematika, 6(1), 91-101. 